\title{
SNCA Gene
}

National Cancer Institute

\section{Source}

National Cancer Institute. SNCA Gene. NCI Thesaurus. Code C90101.

This gene plays a role in neuronal signaling. 